\title{
PERAN DAN FUNGSI DPD RI \\ DALAM RANGKA MENUJU SISTEM BIKAMERAL YANG EFEKTIF MELALUI AMANDEMEN
}

\author{
Wahyu Widodo \\ Dosen Universitas PGRI Semarang \\ wahyu.widodo00@yahoo.com
}

\begin{abstract}
An important aspect in the process of Indonesia's transition to democracy is in the field of constitutional reforms set out in the 1945 Constitution amendment One of the important change is in the form of a new state agency called the Regional Representative Council (DPD). Since the amendment, Indonesian parliamentary system has changed from a system of unicameral to a bicameral system. Manifestations of this institution has awakened hope that the local community problems of the region can be fought at the national level. However, if the note functions, powers and duties set out in Article 22 D the 1945 Constitution and Act 22 of 2003 concerning the composition and position of the MPR, Parliament, DPD and local parliament, then raised a lot of assumptions that are functions of the Regional Representative Council can represent regional interests. DPD is not only serves as a counseling board autonomy, does not serve as the country's legislature adopts a bicameral. Amendments to the Constitution of 1945 is the main road to strengthen the position of this institution as the legislature to assist the Parliament.
\end{abstract}

Keyword : The role and function of the DPD, Bicameral Systems, fifth Amendment of constitutions.

\begin{abstract}
Abstrak
Sebuah aspek penting dalam proses transisi Indonesia menuju ke demokrasi adalah reformasi dibidang ketatanegaraan yang diatur dalam amandemen UUD 1945 salah satu dari perubahan penting adalah dalam membentuk sebuah lembaga negara baru bernama Dewan Perwakilan Daerah (DPD). Sejak dilakukannya amandemen, sistem parlemen Indonesia telah berubah dari sistem unikameral ke sistem bikameral. Manifestasi dari lembaga ini telah terbangun harapan masyarakat daerah bahwa permasalahan daerah dapat diperjuangkan ditingkat nasional. tetapi, jika diperhatikan fungsi, wewenang dan tugas yang telah diatur dalam Pasal 22 D UUD 1945 dan Undang-Undang No.22 Tahun 2003 tentang susunan dan kedudukan MPR,DPR, DPD dan DPRD, maka timbul banyak anggapan bahwa apakah fungsi dari Dewan Perwakilan Daerah dapat mewakili kepentingan daerah. DPD tidak hanya berfungsi sebagai konseling dewan otonomi daerah, tidak melayani lembaga legislatif sebagai negara yang menganut sistem bikameral. Amandemen konstitusi 1945 adalah jalan utama untuk memperkuat posisi lembaga ini sebagai lembaga legislatif untuk mendampingi DPR.
\end{abstract}

kata kunci: Peran dan fungsi DPD, Sistem Bikameral, Amandemen ke-5 UUD 1945.

\section{A. Pendahuluan}

Salah satu perubahan penting dalam amandemen Undang-Undang Dasar 1945 adalah pembentukan lembaga negara baru, yaitu Dewan Perwakilan Daerah (DPD). Pembentukan DPD senafas dengan semangat otonomi daerah, yaitu perlu adanya lembaga negara yang menjembatani kepentingan pusat dan daerah, serta memperjuangkan kepentingan aspirasi masyarakat dan daerah dalam kebijakan nasional.

Keberadaan DPD telah membangkitkan harapan masyarakat di daerah bahwa kepentingan 
daerah dan masalah-masalah yang dihadapi daerah dapat diangkat dan diperjuangkan di tingkat nasional. Bahwa kebijakan-kebijakan publik baik di tingkat nasional maupun daerah tidak merugikan dan bahkan berpihak kepada kepentingan daerah dan kepentingan rakyat di seluruh tanah air. Secara legal, keberadaan DPD tercantum dalam Undang-Undang Nomor 22 Tahun 2003 tentang Susunan dan Kedudukan (Susduk) MPR, DPR, DPD dan DPRD. Namun jarang disebutkan bahwa tugas, fungsi dan wewenang DPD menurut Undang-Undang Nomor 22 Tahun 2003 hanyalah subordinat DPR.

Munculnya ide kamar kedua bertumpu pada keinginan memberi ruang "checks and balances" serta saling mengisi secara kreatif antara dua lembaga parlemen. Sepintas ingin sejalan dengan model perwakilan sistem dua kamar murni (strong bicameralism) seperti di Amerika dengan "House of Representative" (DPR) dan Senat atau Dewan Negara dan Dewan Rakyat di Malaysia. Jika itu yang diterapkan, DPD memiliki hak legislasi, pengawasan dan anggaran yang cukup bertenaga sebagai counterpart DPR. ${ }^{1}$

Jika struktur politik seperti ini masih dipertahankan, maka masa depan DPD sebagai penyeimbang DPR dalam sistem bikameral jadi agak mengkhawatirkan. Di saat kinerja DPR kurang maksimal maka bandul demokrasi pun akan bergerak ke titik yang pesimis. DPR dan DPD semestinya memiliki kewenangan, fungsi dan hak yang setara agar kelemahan DPR tersebut bisa ditutupi oleh masifnya kinerja DPD.

DPD diharapkan menjadi salah satu kamar dari sistem parlemen dua kamar dalam format baru perwakilan politik Indonesia. DPD adalah parlemen yang mewakili wilayah atau daerah dalam hal ini provinsi. Tetapi, struktur ini tidak sepenuhnya mencerminkan sistem bikameral. DPD yang semestinya salah satu kamar dari sistem dua kamar, tidak mempunyai kekuasaan yang memadai. Kewenangan DPD hanya terbatas pada kekuasaan-kekuasaan yang berkaitan dengan otonomi daerah, hubungan pusat dan daerah, pembentukan dan pemekaran serta penggabungan daerah, pengelolaan sumber daya

1 M.Ichsan Loulembah, 2006, Bikameral Bukan Federal, artikel DPD dan Perwakilan Politik Daerah Kelompok DPD di MPR RI, hlm.139. alam dan sumber ekonomi lainnya, serta masalah perimbangan keuangan Pusat dan Daerah (Pasal 22 Undang-Undang Dasar 1945). Diluar itu, kekuasaan DPD hanya memberi pertimbangan kepada DPR. Dengan demikian, keberadaan DPD relatif tidak berfungsi.

Meskipun merupakan representasi daerahdaerah yang telah dipilih langsung oleh rakyat namun keberadaan DPD dapat di ibaratkan antara "ada dan tiada". Betapa tidak karena fungsi dan wewenang yang dimiliki oleh DPD hanya terbatas tidak seperti yang dimiliki oleh DPR. Dampak lainnya adalah, tidak terjadi checks and balances antara DPR dan DPD itu sendiri.

Berdasarkan latar belakang masalah inilah, penulis tertarik untuk melakukan sebuah penelitian yang berjudul: "Rekonstruksi Peran Dan Fungsi DPD RI Dalam Rangka Menuju Sistem Bikameral Yang Efektif Melalui Amandemen".

Berdasarkan paparan latar belakang di atas maka dalam penulisan jurnal ini penulis tertarik membahas mengenai:

1. Bagaimana peran dan fungsi DPD RI dalam rangka menuju sistem bikameral yang efektif melalui amandemen?

2. Bagaimana kelemahan fungsi, tugas dan wewenang DPD, sehingga dapat ditemukan alternatif solusi yang terbaik dalam rangka menuju sistem bikameral yang efektif?

\section{B. Metode Penelitian}

Pendekatan yang digunakan dalam penelitian ini adalah yuridis normatif, yaitu penelitian yang dalam pengkajiannya dengan mengacu dan mendasarkan pada norma-norma dan kaidahkaidah hukum, peraturan perundang-undangan yang berlaku, teori-teori dan doktrin hukum, yurisprudensi dan bahan-bahan kepustakaan lainnya yang relevan dengan topik penelitian. ${ }^{2}$

Sesuai dengan pendekatan yuridis normatif, sumber data dalam penelitian ini hanya berupa data sekunder, yang berupa bahan hukum primair, sekunder dan tertier. Untuk memperoleh bahanbahan hukum yang diperlukan, dilakukan dengan cara penelusuran, pengumpulan dan pengkajian bahan-bahan kepustakaan, peraturan perundang-

2 Soerjono Soekanto, 2001, Pengantar Penelitian Hukum, UI-Press, Jakarta, hlm.24. 
undangan, hasil penelitian, karya-karya ilmiah serta dokumen-dokumen tertulis lainnya.

\section{HASIL PENELITIAN DAN PEMBAHASAN}

1. Peran dan Fungsi DPD RI Dalam Rangka Menuju Sistem Bikameral Yang Efektif Melalui Amandemen.

Munculnya gagasan amandemen kelima Undang-Undang Dasar 1945 salah satunya dilatarbelakangi oleh pandangan yang mengansumsikan Undang-Undang Dasar 1945 hasil amandemen keempat masih memiliki banyak kekurangan. Menurut Syamsuddin Haris, peneliti Lembaga IImu Pengetahuan Indonesia (LIPI), kekurangan tersebut dapat dilihat dari sifatnya masih tambal sulam, proses amandemen yang hanya terjebak pada kepentingan jangka pendek, perubahan tidak sistematik dan tidak terpola, serta kualitas dan substansinya tidak koheren dan inkonsisten. ${ }^{3}$

Sebuah suasana demokrasi yang benar-benar hidup dan belum pernah kita rasakan pada periode sebelumnya ${ }^{4}$. Gagasan amandemen ini sebenarnya sudah muncul sejak awal 2008 yaitu ketika Pemerintah dan DPR sepakat menyiapkan proses perubahan kelima Undang-Undang Dasar 1945 secara menyeluruh dengan segera membentuk panitia/komisi nasional. Kesepakatan itu diambil dalam rapat konsultasi di Istana Negara Jakarta, Jumat 25 Januari $2008^{5}$.

Seiring dengan berjalannya waktu, demi terwujudnya amandemen kelima yang dianggap penting guna menyempurnakan konstitusi, Dewan Perwakilan Daerah (DPD) terus melakukan sosialisasi perubahan kelima Undang-Undang Dasar 1945 yang bertujuan menumbuhkan semangat konsensus nasional mengenai perlunya penataan terhadap sistem

3 www.hukumonline.com diunduh pada 14 Agustus 2014.

4 Ni'matul Huda, 2001, Hukum Tata Negara Indonesia, Jakarta, Penerbit PT. Raja Grafindo Persada. hlm. 213.

5 Ibid. ketatanegaraan Indonesia ${ }^{6}$. Disamping itu, maksud dari sosialisasi juga untuk mendapatkan dukungan dari seluruh elemen masyarakat. Adapun dasar yang menjadi bahan pertimbangan amandemen kelima diantaranya adalah kedudukan DPD yang belum efektif, sistem check and balances antar lembaga negara yang masih kacau, kebingungan mengenai kedudukan MPR, menjamurnya komisikomisi dan lembaga negara, format pemerintah daerah yang belum bagus, format, sistematika, koherensi, dan konsistensi Undang-Undang Dasar 1945 yang masih kacau dan bentuk negara kesatuan yang belum berhasil mewujudkan kesejahteraan. ${ }^{7}$

Diantara agenda yang dirancang dalam gagasan amandemen kelima UUD 1945, Adapun yang menjadi pertimbangan penulis dalam menguatkan fungsi DPD didasarkan pada 5 alasan:

1. Seperti yang kita ketahui bahwa DPD lahir setelah MPR menyetujui perubahan ketiga Undang-Undang Dasar 1945, Lembaga DPD lahir dengan semangat untuk memperkuat sistem demokrasi di Indonesia. Kekuasaan penyelenggaraan negara yang terpusat di lembaga eksekutif selama beberapa dekade telah menimbulkan disparitas sosial dan ekonomi antara Pemerintah (pusat) dan Pemerintah Daerah. Dengan lahirnya DPD, muncul harapan besar untuk dapat memperjuangakan kepentingan-kepentingan daerah guna membangun dan mengembangkan daerahnya. Di samping itu, dengan lahirnya DPD ini secara tidak langsung mengubah wajah parlemen kita menjadi parlemen bikameral yaitu sistem dua kamar, kamar pertama ditempati olehDPR sebagai perwakilan rakyat dan kamar kedua ditempati

6 www.kompas.com diunduh pada 14 Agustus 2014.

7 www.hukumonline.com diunduh pada 14 Agustus 2014 
oleh DPD sebagai perwakilan daerah. Dengan adanya DPD ini dimaksudkan pula agar terciptanya prinsip perimbangan (check and balances) di antara dua lembaga negara tersebut guna menghindari penyalahgunaan kekuasaan atau tindakan melampaui wewenang.

2. Menurut Denny Indrayana meskipun DPD secara jelas hadir sebagai lembaga negara, namun keberadaannya hampir sama dengan ketiadaannya. DPD ada karena salah satunya karena legitimasinya yang relatif kuat. Para anggotanya dipilih langsung melalui sistem pemilu distrik berwakil banyak. Namun, DPD juga 'tiada'. Karena, kuatnya legitimasi hasil pemilu itu tidak berjalan seiring dengan kewenangannya yang cenderung minimalis, terlebih jika dikomparasikan dengan kewenangan DPR $^{8}$. Didalam UUD 1945 perubahan yang keempat, DPD sama sekali tidak mempunyai kekuasaan yang signifikan. DPD hanya memberikan masukan pertimbangan, usul, ataupun saran. Hal ini dapat dilihat pada Pasal 22D yang mengatur tentang kewenangan DPD. Sedangkan yang berhak memutuskan adalah DPR. Sehingga keberadaan DPD di samping DPR tidak dapat disebut sebagai bikameralisme dalam arti lazim. ${ }^{9}$. Dengan keberadaan DPD yang demikian lemah dibanding DPR yang mempunyai kewenangan yang banyak (powerfull) berdampak pada terhambatnya sistem check and balances di antara dua lembaga tersebut.

3. Penerapan sistem kamar parlemen selama ini dipahami bahwa kedudukan kedua kamar itu dibidang legislatif sama kuat, maka sifat bikameralismenya disebut 'strong

8 Denny Indrayana, 2008, Mendesain Presiden Yang Efektif, PT Kompas Media, Jakarta, hlm.299.

9 Ni'matul Huda, Op Cit .hlm. 238. bicameralism', tetapi jika kedua kamar tidak sama kuat, maka disebut 'soft bicameralism'. Akan tetapi dalam pengaturan UUD 1945 pasca perubahan keempat, bukan saja bahwa struktur yang dianut tidak dapat disebut sebagai 'strong bicameralism' yang kedudukannya tidak sama kuat' tetapi bahkan juga tidak dapat disebut sebagai 'soft bicameralism'. Dengan kata lain bahwa DPD hanya memberikan masukan, sedangkan yang memutuskan adalah DPR, sehingga DPD lebih tepat disebut sebagai dewan pertimbangan DPR, karena kedudukannya hanya memberikan pertimbangan DPR ${ }^{10}$.

4. Fungsi, tugas, dan wewenang DPD yang sudah terbatas dalam UUD 1945 lebih dibatasi lagi oleh peraturan perundang-undangan di bawahnya. Dalam Undang-Undang Nomor 27 Tahun 2009 tentang Susunan dan Kedudukan MPR, DPR, DPD, dan DPRD Pasal 150 diatur keikutsertaan DPD dalam pembahasan Rancangan Undang-Undang tertentu antara DPR dan Pemerintah hanya pada awal Pembicaraan Tingkat I di DPR, sehingga DPD tidak dapat berperan optimal dalam pembentukan legislasi. Sedangkan Undang-Undang Nomor 11 Tahun 2012 tentang Pembentukan Peraturan Perundang-undangan hanya mengatur kewenangan DPR dan Pemerintah dalam penentuan prioritas Prolegnas tanpa keterlibatan DPD, serta tidak mengatur hal-hal lainnya secara lebih rinci sehingga dalam prakteknya DPD acapkali mengajukan suatu Rancangan Undang-Undang di luar prioritas pembahasan pada tahun anggaran yang bersangkutan. Hal ini tentu saja membawa dampak yuridis tertentu, karena usulan DPD seringkali hanya terhenti sebatas disampaikan dalam suatu acara yang bersifat seremonial antara Pimpinan

10 Ibid. 
DPD dengan Pimpinan DPR tanpa adanya tindak lanjut yang berarti secara yuridis konstitusional

5. Alasan yang kelima ini yang menjadi penentu harapan baru untuk dapat merealisasikan penguatan DPD agar dapat sejajar dengan DPR yaitu melalui perubahan UUD 1945. Karena UUD 1945 merupakan sumber hukum tertinggi, dan Undang-Undang merupakan produk hukum turunannya yang berisi aturan yang lebih teknis. Bila penguatan kewenangan DPD hanya dilakukan melalui revisi UndangUndang, maka peran DPD tetap tidak dapat optimal mengingat kewenangan DPD yang sangat terbatas dalam UUD 1945.

Dari kelima alasan yang telah penulis paparkan di atas terlihat bahwa terjadi ketidakseimbangan antara DPD dan DPR sehingga menyebabkan sistem parlemen berdampak pada cacatnya sistem legislasi. Dengan demikian, dalam gagasan amandemen UndangUndang Dasar 1945 kelima ini usulan DPD kedepan terkait dengan fungsi dan kewenangannya adalah sebagai berikut:

1. Dalam bidang legislasi Dewan Perwakilan Daerah harus diberikan kewenangan yang sama dengan DPR. Dewan Perwakilan Daerah tidak hanya terbatas memberikan pertimbangan, tetapi juga turut mempunyai hak suara untuk menentukan lolos tidaknya Rancangan Undang-Undang (RUU). Seperti yang dijelaskan dalam Undang-Undang No 27 tahun 2009 bahwa terdapat dua tingkat pembicaraan yaitu pembicaraan pertama menyangkut pengantar musyawarah, pembahasan daftar inventaris masalah; dan penyampaian pendapat. Kemudian pembicaraan kedua merupakan pengambilan keputusan paripurna. Dalam hal ini DPD harus diikutsertakan dalam pembicaraan tahap kedua untuk ikut serta dalam keputusan paripurna.
2. Dalam menegakkan prinsip perimbangan (check and balances) antara DPD dan DPR, DPR RI yang anggotanya dipilih berdasar jumlah penduduk dan melalui partai-partai, maka Anggota DPD dipilih berdasar keterwakilan daerah dan secara perseorangan. Kedua sistem ini bisa saling mengisi, mengimbangi, dan menjaga (checks and balances) antar lembaga perwakilan. Sebagai perbandingan, di Amerika Serikat, senat setiap anggota bagian memiliki 2 (dua) orang senator untuk mewakili mereka dalam senat, tidak tergantung dari luas daerah dan jumlah penduduk di negara bagian tersebut. Para senator dipilih melalui pemilu lokal dan memiliki jabatan selama 6 tahun. Penggantian senator tidak dilakukan serentak. Setiap 2 tahun sekali diadakan pemilihan anggota senat, di mana $1 / 3$ dari anggota senat habis masa jabatannya dan diganti dengan anggota baru ${ }^{11}$.

3. Kewenangan pengawasan (oversight) DPD harus memiliki kekuatan hukum yang sama dengan DPR, agar pengawasan tersebut bisa efektif. Kemudian hasil pengawasannya tidak hanya disampaikan kepada DPR tetapi juga kepada Pemerintah untuk ditindaklanjuti. Untuk menghindari terjadinya duplikasi dengan DPR dapat diatur pembagian kewenangan dan tanggungjawab pengawasan antara kedua lembaga tersebut. Misalnya, dalam pengawasan DPD lebih terfokus di daerah dan DPR RI di pusat.

Dengan lahirnya DPD pasca amandemen ketiga mengubah wajah parlemen menjadi parlemen bikameral. Menurut Giovanni Sartori bahwa sistem bikameral yang ideal adalah strong bicameral yaitu apabila kekuatan antara dua kamarnya nyaris sama kuat.

11 Sinamo Nomensen, 2010, Hukum Anggaran Negara, Pustaka Mandiri, Jakarta: hlm.138-139. 
Jamak diketahui bahwa UUD 1945 hasil amandemen keempat sama sekali belum memberikan DPD kewenangan yang seimbang dengan DPR. Apalagi hasil amandemen tersebut cendrung mengarah kepada legislative heavy, sehingga DPD tidak dapat mempunyai daya untuk mengimbangi DPR. Dengan demikian untuk mewujudkan strong bicameralyang ideal maka dalam gagasan amandemen kelima, DPD harus diperkuat. yaitu:

1. Dibidang legislasi DPD harus mempunyai kewenangan yang sama dengan DPR dalam membahas RUU. Tidak hanya memberikan pertimbangan dan usulan saja melainkan juga memberikan suara lolos tidaknya RUU yang dibahas tersebut.

2. Untukmenegakkan checkandbalances antara DPD dan DPR, DPD Anggota DPD dipilih berdasar keterwakilan daerah dan secara perseorangan. Sehingga kedua lembaga ini saling mengisi, mengimbangidanmenjaga.

3. Dalam bidang pengawasan, kewenganan pengawasan DPD harus mempunyai kekuatan hukum yang sama dengan DPR. Kemudian hasil pengawasan tersebut tidak hanya diserahkan kepada DPR RI tapi juga kepada pemerintah untuk ditindaklanjuti.

2. Kelemahan fungsi, tugas dan wewenang DPD, sehingga dapat ditemukan alternatif solusi yang terbaik dalam rangka menuju sistem bikameral yang efektif

Di sebagian besar negara para anggota mewakili negara bagian, provinsi atau wilayah perwakilan dengan jumlah yang sama. Di sebagian negara lagi jumlahnya proporsional terhadap jumlah penduduk, sedangkan di sebagian lainnya merupakan kombinasi. Namun ada pula yang dipih secara nasional, tidak mewakili daerah tertentu (National District seperti Filipina) atau diangkat atas pertimbangan lain.
Keanggotaan majelis tinggi dibatasi dalam periode tertentu, ada yang sama dengan periode DPR namun banyak pula yang berbeda. Umumnya lebih panjang, seperti 6 tahun di As, 9 tahun di Perancis atau bahkan seumur hidup seperti di Inggris. Mengenai kewenangan, senat atau majelis tinggi memiliki kewenangan tertentu dalam legislasi dan pengawasan meskipun tingkat kewenangan tersebut bervariasi di satu negara dengan negara lainnya.

Sistem bikameral dalam sistem perwakilan di berbagai negara pada umumnya atas dua pertimbangan: ${ }^{12}$

1. Representatives

Perlunya perwakilan yang lebih luas daripada hanya atas dasar jumlah penduduk. Dalam hal ini yang paling utama adalah pertimbangan keterwakilan wilayah.

2. Redundancy

Perlu adanya sistem yang menjamin bahwa keputusan-keputusan politik yang penting, dibahas secara berlapis sehingga berbagai kepentingan dipertimbangkan secara masak dan mendalam.

Menurut pendapat para ahli, sistem bikameral mencerminkan prinsip check and balances bukan hanya antar cabangcabang kekuasaan negara (legislatif, eksekutif, yudikatif) tapi juga di dalam cabang legislatif itu sendiri. Dengan demikian maka sistem bikameral dapat lebih terjadinya tirani mayoritas maupun tirani minoritas.

Masalah yang sering ditampilkan sebagai penolakan terhadap sistem bikameral, adalah efisiensi dalam proses legislasi, karena harus melalui dua kamar, maka ada anggapan bahwa sistem bikameral akan menghambat kelancaran dalam pembuatan UndangUndang.

Beberapa negara yang semula menganut sistem bikameral telah beralih

12 Patterson, Samuel C. \& Anthony Mughan, 1999, Senates: Bicameralism In The Contemporary Word, Ohio: Ohio State University, hlm. 18. 
ke unikameral yaitu Selandia Baru (1950), Denmark (1953), Swedia (1971). Namun ada juga yang semula unikameral berubah ke bikameral seperti Comorros (1992) dan Indonesia. Negara-negara yang menganut sistem bikameral dengan caranya masingmasing telah berupaya untuk mengatasi masalah tersebut, antara lain dengan membentuk conference committee untuk menyelesaikan perbedaan yang ada anatara dua majelis tersebut, sehingga dewasa ini persoalan itu tidak dipandang lagi menjadi faktor penghambat.

Dilihat dari segi kewenangan yang dimiliki majelis tinggi, sistem bikameral umumnya dibagi dalam dua kategori kuat dan lemah. Dalam hal majelis tinggi mempunyai kewenagan legislasi dan pengawasan yang sama atau hampir sama dengan majelis rendah, maka sistem bikameral di negara tersebut disebut kuat. Dan dalam hal kewenangan yang dimiliki tersebut kurang kuat atau sama sekali tidak ada maka termasuk kelompok yang lemah.

Keberadaan DPD tidak terlepas dari berbagai latar belakang persoalan lembaga-lembaga Negara di Indonesia. Hal tersebut tentu dimaksudkan untuk mendapatkan sistem kelembagaan politik yang sesuai dengan kondisi masyarakat Indonesia. Sebagai negara kepulauan dengan komposisi etnis yang beragam, bahasa dan agama berbeda, rasanya mustahil satu kelembagaan saja akan mampu menampung seluruh perbedaan itu.

Hal ini senada dengan ungkapan Ketua DPD RI periode 2004-2009, yang menyatakan gagasan dasar pembentukan DPD adalah keinginan untuk lebih mengakomodasi aspirasi daerah dan sekaligus memberi peran yang lebih besar kepada daerah dalam proses pengambilan keputusan politik terutama berkaitan langsung dengan kepentingan daerah. Keinginan tersebut berangkat dari pemikiran bahwa pengambilan keputusan yang bersifat sentralistik pada zaman yang lalu ternyata telah mengakibatkan ketimpangan dan rasa ketidakadilan, sehingga dapat membahayakan stabilitas wilayah negara dan persatuan nasional. Keberadaan unsur utusan daerah didalam keanggotaan MPR selama ini (sebelum dilakukannya perubahan terhadap UUD 1945) dianggap tidak dapat menjawab tantangan tersebut. ${ }^{13}$

Keberadaan DPD diperkirakan Indonesia akan menganut sistem bikameral dan memperkuat sistem parlemen ternyata dilihat dari uraian Pasal-Pasal yang mengatur fungsi, tugas dan wewenang DPD dalam UndangUndangD 1945 dan Undang-Undang Nomor 22 Tahun 2003 tentang Susunan dan Kedudukan (Susduk) MPR, DPR, DPD dan DPRD tidak demikian.

Fungsi, tugas dan wewenang DPD: ${ }^{14}$

1. Fungsi Legislasi

Dapat mengajukan RUU kepada DPR dan ikut membahas RUU yang terkait dengan otonomi daerah, hubungan Pusat dan Daerah, pembentukan dan pemekaran serta penggabungan daerah, pengelolaan sumber daya alam dan sumber daya ekonomi lainnya, perimbangan keuangan pusat dan daerah.

2. Fungsi Konsultasi Memberikan pertimbangan kepada DPR dalam hal RUU APBN, RUU yang berkaitan dengan pajak, pendidikan dan agama serta pemilihan anggota BPK.

3. Fungsi Pengawasan

Dapat melakukan pengawasan atas pelaksanaan Undang-Undang dan menyampaikan hasil pengawasannya kepada DPR sebagai bahan pertimbangan untuk ditindaklanjuti terkait dengan otonomi daerah,

13 Ginandjar Kartasasmita selaku Ketua DPD RI Periode 2004-2009, Makalah yang berjudul "Bikameralisme Di Indonesia" disampaikan acara seminar sehari, Jakarta 2 Maret 2006.

14 Kelompok DPD di MPR RI, 2006, Bikameral Bukan Federal, artikel DPD dan Perwakilan Politik Daerah oleh M. Ichsan Loulembah. ,hlm.139. 
hubungan pusat dan daerah, pembentukan dan pemekaran serta penggabungan daerah, pengelolaan sumber daya alam dan sumber daya ekonomi lainnya, pertimbangan keuangan pusat dan daerah, pelaksanaan APBN, pajak, agama, pendidikan, serta menerima hasil audit keuangan negara yang dilakukan oleh BPK.

4. Fungsi Anggaran

Dapat mengajukan RUU tentang perimbangan keuangan pusat serta daerah, memberikan pertimbangan terhadap RUU APBN, melakukan pengawasan terhadap pelaksanaan APBN.

Berdasarkan kewenangan yang terdapat dalam Pasal 22D UUD 1945 tidak dikatakan bahwa DPD mempunyai fungsi legislasi. Bagaimanapun, dalam teori perundang-undangan, fungsi legislasi harus dilihat secara utuh, yaitu dimulai dari proses pengajuan sampai menyetujui sebuah Rancangan Undang-Undang menjadi UndangUndang. Ketimpangan fungsi legislasi menjadi semakin nyata dengan adanya penegasan Pasal 20 Ayat (1) UUD 1945 bahwa kekuasaan membentuk Undang-Undang berada di tangan DPR. Tambah lagi, Pasal 20 A ayat (1) UUD 1945 secara eksplisit hanya menyebut DPR sebagai pemilik kekuasaan legislasi.

Berkaca pada praktik beberapa negara, dalam sistem bikameral, ketimpangan fungsi legislasi dapat saja terjadi. Menurut Kevin Evans ${ }^{15}$ kalau majelis tinggi tidak mempunyai fungsi legislasi secara utuh, maka majelis tinggi berhak mengubah, melakukan pertimbangan atau menolak Rancangan Undang-Undang

15 Kevin Evans, 2002, Seputar Sistem Bikameral, dalam Bambang Subianto et.al (edit.), Menggagas Ulang Prinsip-prinsip Lembaga Kepresidenan, CPPS Paramadina dan Partnership for Governance Reform in Indonesia, Jakarta. hlm. 32. dari majelis rendah. Sekiranya hak itu juga tidak ada, majelis tinggi diberi hak menunda pengesahan Rancangan Undang-Undang yang disetujui majelis rendah. Hak menunda pengesahan itu, tambah Evans, sering menjadi satu-satunya kekuatan jika majelis tinggi tidak mempunyai hak mengubah dan menolak Rancangan UndangUndang. ${ }^{16}$

Uniknya lagi, DPD tidak jelas disebut sebagai lembaga apa. DPD bukan lembaga yudikatif, legislatif, apalagi eksekutif. DPD lebih mirip sebagai perluasan dari Dewan Pertimbangan Otonomi Daerah (DPOD), karena hanya mengajukan dan membahas Rancangan Undang-Undang, pertimbangan atas Rancangan Undang-Undang (termasukAPBN, pajak, pendidikan dan agama) dan pengawasan pelaksanaan Undang-Undang itu, tanpa ikut dalam memutuskan Rancangan UndangUndang tersebut menjadi UndangUndang, juga memberikan kontrol rutin atas kinerja pemerintahan daerah. Sistem ini dikenal sebagai weak bicameralism, seperti diterapkan di Inggris, Botswana dan Burkina Faso.

Hegemoni DPR terhadap DPD, sangat berpotensi melahirkan superioritas DPR dalam negara. DPD tidak lebih dari sekedar wakil yang duduk dalam bidang legislasi. Ketiadaan fungsi legislasi bagi DPD ini, bisa dimaklumi, karena sistem bikameral Indonesia lahir sebagai karbitan yang kering, tanpa roh. Sistem perwakilan Indonesia hanya memiliki roh, jika itu lahir dari situasi, kebutuhan dan diperoleh dari dinamika masyarakat.

Apabila dikaji lebih dalam, ada dua argumentasi mengenai kebutuhan akan bikameral yang efektif. Pertama, untuk membawa kebutuhan dan kepentingan daerah dalam tingkat nasional. DPR

16 Kelompok DPD di MPR RI, Op cit, hlm.5. 
sendirian masih belum cukup untuk dapat melakukan peran ini. Misalnya, masih banyak Undang-Undang yang belum dapat secara maksimal mengakomodasi kepentingan daerah, yang paling terlihat Undang-Undang yang diajukan kepada Mahkamah Konstitusi untuk uji materil yang tidak mengakomodasi kepentingan daerah. Undang-Undang Nomor 32 Tahun 2004 tentang Pemerintahan Daerah diajukan ke Mahkamah Konstitusi oleh berbagai pihak karena muatannya tidak memperhatikan realitas daerah. ${ }^{17}$

Kedua, untuk mendorong kekuatan politik penyeimbang di dalam parlemen. Persoalannya bukan pada tubuh DPR itu sendiri, tapi memang keberadaan suatu kamar lain di dalam legislatif sebagai kekuatan penyeimbang yang penting. Dengan adanya DPD yang berkedudukan setara, walau mungkin akan fokus wewenang yang berbeda, akan ada mitra DPR untuk membahas segala keputusan yang diambilnya. Dengan keputusan yang diambil oleh legislatif telah melalui pertimbangan yang lebih baik. Apalagi sifat kelembagaan disebabkan oleh asal muasal anggotanya akan menyebabkan adanya perbedaan pandangan, yang pada gilirannya keputusan lebih seksama dipertimbangkan. ${ }^{18}$

Penyimpulan yang paling tepat bukan lagi mempertanyakan perlu atau tidaknya DPD, melainkan bagaimana caranya agar ada suatu dewan yang dapat secara efektif mengakomodasi kebutuhan daerah di tingkat nasional. Berikut ada beberapa pendapat tentang cara mengefektifkan DPD dalam menjalankan fungsi, tugas dan wewenangnya sebagai wakil dari kepentingan daerah: ${ }^{19}$

17 Ibid.

18 Ibid.

19 Kelompok DPD di MPR RI, 2007, Untuk Apa DPD $R I$, hlm. 118.
1. Perubahan Konstitusi

Akar permasalahan dari keterbatasan kewenangan DPD, tidak dapat dipungkiri adalah pengaturan mengenai DPD dalam konstitusi. Ketentuan yang harus diubah adalah Pasal $22 \mathrm{D}$ yang mengatur keberadaan DPD, terutama keterbatasan wewenang DPD. Wilayah konstitusional antara DPR dan DPD menjadi isu politik yang makin memanas, karena adanya keinginan dari sejumlah anggota DPD untuk mengajukan inisiatif amandemen UUD 1945. Meski begitu, sama sekali tidak mudah untuk mendorong amandemen UUD 1945 untuk yang ke-lima kalinya. Dari segi prosedur, berdasarkan Pasal 37 UUD 1945, untuk dapat memulai pembicaraan mengenai perubahan UUD 1945, sepertiga anggota MPR harus mengajukannya. Namun, DPD tidak boleh pesimis, tetapi DPD harus mengintensifkan pendekatan, lobi dan pemberian penawaran politik berupa terbukanya kesempatan juga bagi partai politik untuk menempatkan kader terbaiknya dalam pemilu DPD. Lobi-lobi ini harus dimaknai sebagai sebuah pekerjaan rumah yang mengikat bagi selurh anggota DPD untuk bersama-sama memperjuangkan lembaga yang menaunginya agar minimal setara dan memiliki tugas, fungsi dan wewenang yang sama dengan DPR. Selain itu, DPD harus mengupayakan secara terus-menerus kerja sama antara DPD dan DPR untuk penyelesaian berbagai permasalahan kebangsaan. Kerja sama yang terus menerus dapat diasumsikan akan mampu mencairkan kebekuan dan kebuntuan sikap penolakan dari DPR untuk mendorong penguatan DPD agar mampu membangun struktur ketatanegaraan yang baik. 
2. Konvensi Ketatanegaran

Upaya lain yang perlu didorong dan didukung selain perubahan konstitusi adalah lahirnya konvensi ketatanegaraan baru adalah lahirnya konvensi ketatanegaraan baru yang dapat membuat eksistensi DPD lebih dikuatkan. Konvensi ketatanegaraan yang dimaksud adalah praktek ketatanegaraan yang lahir bukan karena adanya pengaturan, melainkan karena tradisi.

Di beberapa negara, konvensi ketatanegaraan seringkali mempunyai peran yang penting dalam proses politik. Di Amerika Serikat, misalnya wewenang House of Representatives untuk mengajukan APBN merupakan sebuah konvensi ketatanegaraan yang lahir karena House of Representatives dianggap lebih dekat dengan publik.

Pidato Presiden di hadapan MPR setiap 16 Agustus adalah konvensi ketatanegaraan. Karena itulah, pidato kenegaraan Presiden tanggal 16 Agustus 2005 yang mengikutsertakan DPD, maka menimbulkan dua arti penting.

1. DPD telah diakui keberadaannya sebagai suatu bagian dari lembaga legislatif yang harus diperhitungkan oleh Presiden dalam pembuatan kebijakan.

2. Pengakuan akan peran DPD sebagai penyeimbang kepentingan nasional dan aspirasi daerah. Konvensi ketatanegaraan mengenai pidato Presiden 16 Agustus 2005 menginspirasikan munculnya konvesni-konvensi ketatanegaraan lain yang dapat memperkuat kedudukan DPD. Konvensi ketatanegaraan ini dapat mengisi ruang kosong pengaturan wewenang DPD. Masih perlu dilihat lebih jauh dimana konvensi ini dapat didorong. Harapannya, dengan kesadaran bahwa penguatan
DPD dibutuhkan, akan ada dukungan dari lembaga negara lain maupun dari publik untuk mendorong adanya konvensi ketatanegaraan lainnya.

3. Penguatan Institusional Hal lain yang harus dilakukan untuk mengefektifkan keberadaan DPD dalam rangka menuju sistem bikameral yang efektif adalah penguatan institusional. Wewenang DPD memang sangat terbatas, namun perannya sebagai wakil rakyat tidak akan bisa dibatasi.

\section{PENUTUP}

\section{Kesimpulan}

a. Keberadaan DPD sebagi lembaga legislatif belum lagi mencerminkan sistem bikameral yag selama ini didambakan oleh negara Indonesia. Hal ini terlihat dari otoritas dan peran DPD yang tidak seimbang dengan DPR. DPD diibaratkan hanya sebagai Dewan Pertimbangan Otonomi Daerah bukan sebagai lembaga legislatif mendampingi DPR. Sistem bikameral yang dianut Indonesia hanya setengah hati, maksudnya mencontek sistem bikameral Amerika tetapi hanya sebagian saja.

b. Ada tiga upaya untuk memposisikan DPD sebagai lembaga penyeimbang bagi DPR demi menuju sistem bikameral yang efektif, yaitu : perubahan konstitusi, konvensi ketatanegaraan dan penguatan institusional.

\section{Saran}

a. Sebaiknya usulan atau pendapat yang ingin membubarkan DPD dapat diminimalisir, karena akan mempersulit upaya DPD melakukan penguatan institusional. DPD merupakan lembaga yang harus dipertahankan keberadaannya sebagai lembaga penyeimbang DPR serta fasilitator aspirasi daerah. 
b. Sebaiknya DPD tetap berupaya melakukan lobi-lobi politiknya kepada DPR maupun Presiden untuk dapat memperkuat otoritas dan perannya sebagai lembaga legislatif, serta terus berupaya mendesak amandemen kelima UUD 1945.

\section{DAFTAR PUSTAKA}

\section{- Buku-Buku :}

Denny Indrayana, 2008, Mendesain Presiden Yang Efektif, PT Kompas Media, Jakarta.

Ni'matul Huda, 2001, Hukum Tata Negara Indonesia, Jakarta, PT. Raja Grafindo Persada.

Sinamo Nomensen, 2001, Hukum Anggaran Negara, Pustaka Mandiri, Jakarta.

Soerjono Soekanto, 2001, Pengantar Penelitian Hukum, UI-Press, Jakarta.

Samuel C. Patterson \& Anthony Mughan, 1999, Senates: Bicameralism In The Contemporary Word, Ohio: Ohio State University

\section{- Artikel}

Ginandjar Kartasasmita selaku Ketua DPD RI Periode 2004-2009, Makalah yang berjudul "Bikameralisme Di Indonesia" disampaikan acara seminar sehari, Jakarta 2 Maret 2006.

Kelompok DPD di MPR RI, 2006, Bikameral Bukan Federal, artikel DPD dan Perwakilan Politik Daerah oleh M. Ichsan Loulembah.

Kevin Evans, Seputar Sistem Bikameral, dalam Bambang Subianto et.al (edit.), Menggagas Ulang Prinsip-prinsip Lembaga Kepresidenan, CPPS Paramadina dan Partnership for Governance Reform in Indonesia, Jakarta.2002.

\section{- Website}

www.hukumonline.com

www.kompas.com 